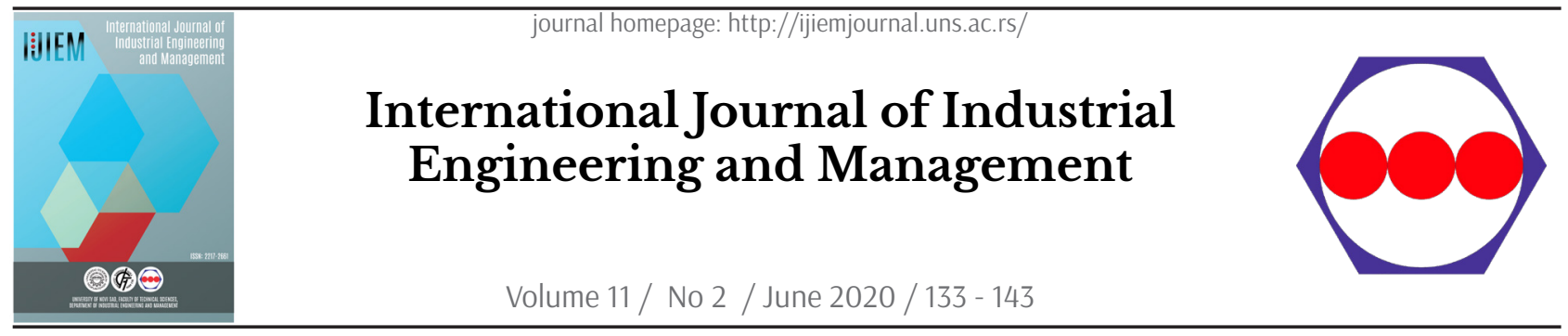

Original research article

\title{
Servitization in manufacturing: role of antecedents and firm characteristics
}

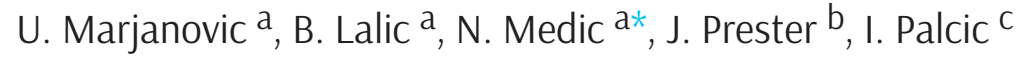 \\ ${ }^{a}$ Faculty of Technical Sciences, University of Novi Sad, Novi Sad; \\ ${ }^{b}$ Faculty of Economics, University of Zagreb, Zagreb, Croatia; \\ ${ }^{c}$ Faculty of Mechanical Engineering, University of Maribor, Maribor, Slovenia
}

\begin{abstract}
A B STRACT
The process of creating value by adding services to product offerings, or servitization, is a mature theme in the literature, flourishing in recent years. Prior research investigated the impact of servitization measured by the share of services on the performance in terms of growth and stability. However, the impact of service antecedents on the share of revenue was neglected. This research intends to shed light on the impact of service portfolio antecedents on firm performance and to investigate the direct vs. indirect charges of services and the interplay of different firm characteristics and the service business model. We used dataset on 474 manufacturing firms from Croatia, Serbia and Slovenia. Results reveal antecedents as well as implications of direct and indirect charging of services in manufacturing firms. In addition, this study demonstrates the interplay of different firm characteristics and servitization.
\end{abstract}

\section{ARTICLE INFO}

Article history:

Received April 28, 2020

Revised June 29, 2020

Accepted June 30, 2020

Published online June 30, 2020

Keywords:

Product-related services;

Manufacturing;

Servitization;

Financial performance;

EMS

*Corresponding author:

Nenad Medic

medic.nenad@uns.ac.rs

\section{Introduction}

The question of 'how can services add value' has been gaining attention among manufacturing firms [1]-[3] due to the opportunity to provide services along with, or instead of their traditional physical products [4], [5]. The literature has looked at the impact of servitization measured by the share of services on performance in terms of growth and stability [6][10], but service portfolio antecedents for the share of revenue have been neglected. Equally, the charging business model of the services of manufacturers is underexplored. Servitization literature recognizes the importance of direct and indirect charging of services, but it considers the service business model from the sales channels perspective rather than the billing option strategy for achieving service growth [11]. This paper investigates and offers an understanding of antecedents as well as direct and indirect charging of services in manufacturing firms.

Servitization is a trend in which durable goods manufacturers choose to innovate their offerings by providing services to accompany their existing products throughout the life cycle [7]. Typical examples of services provided include installation and training, after-sales services (i.e. product repair and mainte- 
nance, customer support and recycling), software development, remote support and modernization [12]-[14]. In recent years, attention has been focused on the trend of servitization within the production research community [1], [15]-[19]. While broadening the perspective from products to services is fundamental to the servitization debate, its impact on a firm's performance remains in question. This is partly due to the fact that the possibility to charge for services that had previously been free represents a challenge to managers [20]. Certainly, the concept of servitization could enhance the competitiveness of a manufacturing firms while simultaneously advancing economic conditions, resulting in a bigger share of turnover from selling services [15], [21]. A key issue for manufacturing firms is their ability to charge for services. An empirical investigation of more than 3000 manufacturing firms shows that the portion of services invoiced indirectly is larger than the directly invoiced portion [22]. Furthermore, for a comprehensive analysis of servitization, it seems therefore necessary to look at particular product-related services, measuring the impact of services on the performance of firms [23], [24]. Studies that deal with the assessment of whether adding particular additional services improves the financial performance of a firm are scarce and more empirical research is needed in this area [7], [24], [25].

This study extends the work presented in [26]. To shed more light on this important area of production research, we investigate how specific service portfolio choices influence financial implications regarding the charging option. For example, the success of service transition strategies could depend on both firm (e.g., firm size) and industry characteristics (e.g., technological intensity) [9]. In support of this view, scholars have called for further research on the moderating variables affecting the success of services [10], [27], [28]. We explore how two key moderator variables (i.e. firm size, product complexity) affect the strength of services and financial performance relationship. This study relies on a unique dataset from the European Manufacturing Survey (EMS) with a sample of 474 industrial firms from three European countries (i.e. Croatia, Serbia and Slovenia). Our analysis shows that not all services are made equal. Some will work better with direct and some with indirect charging. Additionally, firm characteristics are important moderators that affect performance outcomes of service growth strategies in manufacturing firms.

The remainder of this paper is organised as follows: Section 2 gives an overview of the relevant literature on servitization and firm performance. In Sec- tion 3, we develop our research model and present data and research methodology. Section 4 presents results with the use of regression models for each of our research hypotheses. In Section 5, research results are discussed and analysed. Finally, the conclusion, practical implications, limitations and directions for future research are specified in Section 6.

\section{Related research in servitization and firm performance}

The process of creating value by adding services to product offerings, or servitization, has a long presence in the literature [21]. Early studies reported that firms were adding service to their offerings to achieve greater performance - substantial turnover, increased profit, stronger market power, reduced risk and increased competitiveness [29], [30]. A later stream of research argues that manufacturing firms should move toward service and solution providers, or to evolve from 'goods or services' to 'goods and services', to achieve revenue growth [7], [10], [26], [31]-[33] or a growing share of manufacturers' revenues from services [9]. Prior study provides evidence that the average share of service revenues among manufacturing firms increased almost five times in a 15-year period [9]. Moreover, Lay et al. indicated the overall value of sales generated by services was reported to be about 16 percent on average, from which the larger part was realized by services that were invoiced indirectly (i.e. as part of the product's price) [22]. Other literature confirmed the positive effect of services on financial performance measures expressed through revenue [10], profit [7] and firm value [8]. Finally, a literature review analysis of 41 peer-reviewed journal articles confirms a positive servitization-performance relationship [34]. Nevertheless, not all literature found positive effect of servitization. For instance, Benedettini et al. list several examples where companies start withdrawing rather than extending their service offering [35]. They list Johnson Controls, Voith and ABB as disengaging from facilities and maintenance management contracts. Kowalkowski et al. list Xerox as an example of deservitization where Xerox in 2016 withdraw their service offering and formed an independent company Conduent for the service part of their provision [36].

Besides the effect of industrial service strategies on firm performance, previous literature also focused on the identification of variables that moderate the effect of industrial service strategies on firm per- 
formance [10], [37], [38]. For instance, Eggert et al. found two types of moderating contextual variables in prior studies: industry and firm characteristics [10]. According to the study of Fang et al. industry turbulence has a positive, while industry growth has a negative effect on the service-performance relationship [9]. While evidence regarding industry characteristics as a moderating variable is inconclusive, evidence on the firm characteristics to influence the relationship between service offering and performance is more positive. Numerous empirical studies test the assumption that performance outcomes depend on the alignment between the manufacturing service strategy and firm characteristics measured through firm size [6], [10], [31], [38], [39]. For example, Neely found that larger manufacturing firms, measured in terms of numbers of employees, harvest superb performance compared to smaller firms [39]. Furthermore, both Eggert et al. and Suarez et al. found that firm size positively moderates the effect of the breadth of the service portfolio on firms' revenue [6], [10]. Some effort has been made to define the role of product complexity as a moderating contextual variable. For instance, two empirical studies argued that servitization is an important strategy for suppliers of both complex products [4] and non-complex products [27].

Servitization involves more than just provision of more extensive services [40]. It involves firms' evolution in terms of specialization, vertical, horizontal and systematic integration [41]. This is seen as an enabler for value creation by blending services into overall strategies of a firm [25]. The servitization trajectory starts with a business model based solely on products and the provision of obligatory warranties or spare parts [42]. It continues with the inclusion of product-related services (e.g., installation, maintenance, and repairs) where the business model is mainly oriented toward sales of products with additional service offerings. Finally, it moves to the value and customer-oriented business model as the firm gradually adds use-oriented and results-oriented services [8], [42]. Clearly, the adoption of a particular service business model will subsequently have performance implications [8].

From a careful review of this growing body of literature, we identify a need to advance our knowledge in two directions. First, previous literature suggests that a service portfolio offering possibly leads to different consequences for firm performance. To date, however, most empirical research treats services as a bundle [6], [8]. Against this background, this study aims at shedding more light on the service portfolio antecedents for firm performance. Second, previous research on moderator variables does not account for the interplay between service portfolio choices and financial and charging options for the services. Prior research has pointed out the importance of indirect charging [11], [22], and thus, this represents a fruitful area for further examination.

\section{Research model, data and methodology}

\subsection{Theoretical development of the research model}

The product-related services presented in the model were identified based on exploratory interviews with practitioners and group discussions with experts in the field. All EMS consortium members were involved in this process which resulted in a universal transversal list of services so that all manufacturing sectors can apply it regardless of the product offered. Consequently, these product-related services were included in the EMS questionnaire. We use the share of revenue as our dependent variable. The share of revenue was defined as the share of firm revenue in the market [7], [9], [10], [31].

Manufacturers' service-oriented strategies can be characterized by the breadth (i.e., scope) of the service portfolio [10]. Service transition strategies, expressed through the breadth of the service, represent a fundamental shift in a firm's strategic direction [9]. Therefore, they should affect the firm's financial performance. Thus, the more a firm introduces services in its value proposition and the more it considers them to be an important strategic option, the greater is the firm's share of revenue from the services [22]. Hence, the following two hypotheses are proposed:

\section{H1a: The deployment of specific service portfolio choices will positively impact the share of revenue when charged directly. \\ H1b: The deployment of specific service portfolio choices will positively impact the share of revenue when charged indirectly (included in the product price).}

Up to now dominant research on servitization has been done on large multinational companies (i.e. Rolls Royce, ABB, Alstom, Xerox). Key findings proposed by Oliva and Kallenberg and Wise and Baumgartner are not applicable to Small and Medium Enterprises (SME) since SMEs do not usually sell many products on a large scale [29], [43]. They have a small installed base to whom they can offer and sell services. Correspondingly, SMEs do not usually 
sell their products directly but rather through distributors who sometimes become their competitors in service offerings. Moreover, it is argued that the first differentiating factor between SMEs and large firms is sales distribution channels [11]. Most SMEs will not have a direct contact with the customer. Those SMEs that sell through distributors will not even have contact with their customer and thus not even the possibility to offer or sell services and bill them directly. Therefore, SMEs provide a narrow range of services but in a small geographical and technological market niche with limited competitive rivalry and risks of new entrants [44]. Neely suggests that on the average SMEs obtain a bigger share of revenue from services in comparison to larger firms, although the service portfolio differs between smaller and larger firms [39]. Smaller manufacturing firms, as well as large firms, face changing interest rates and risk pooling. Such pre-financing is too expensive for them, so they concentrate only on certain services such as the already mentioned maintenance and repair and design and consulting in local market niches. However, Dachs et al. found that the service share is highest in very large firms [4]. Large firms have the opportunity to sell their products directly and this is the major difference between SMEs and large firms [11]. They have a large installed base and can offer a broad portfolio of services throughout a product's lifecycle. If larger firms transform their business to service logic, they can obtain higher competitive advantage [45] and are even able to outsource non-profitable service provision [44]. Large firms can form collaborations with suppliers, thus, spare parts provision and maintenance is not costly for them. Large and medium manufacturing firms usually consist of several dedicated departments and thus can offer a broader range of services of which some are billed directly, but some can only be billed indirectly due to administration [46]. Finally, Neely claims that servitization of large firms requires incremental investments in staff and capital and, thus, larger firms would benefit more from servitization [39]. However, smaller firms can also obtain better servitization gains. From this point of view, it is possible to propose the following hypotheses:

H2a: The degree of servitization increases with firm size H2b: Firm size moderates the impact of breadth of the product-related service portfolio on the firm's performance.

Besides firm size as a firm characteristic, product complexity plays another important role in the relationship between services and firm performance [27]. In terms of complexity, manufacturing products can be defined as simple products, products with medium complexity, and complex products and systems [27], [47]. Production research literature [4], [17], [27], [48] suggests that manufacturing firms that produce more complex products will achieve a greater turnover from the services since complex products and systems require a wider range (i.e. scope) of services. Hence, product complexity will impact the relationship between services and firm performance. For instance, complex products and systems often require a range of services (e.g. installation, maintenance, repair, training, documentation, call centres and warranty), whereas simple products require only delivery, or could be installed by users. For that reason, we hypothesize:

H3a: The degree of servitization increases with product complexity.

H3b: Product complexity moderates the impact of breadth of the product-related service portfolio on the firm's performance.

\subsection{Research data methodology}

Data for this empirical study derive from the Eu-

Product-related services
(1) Installation
(2) Maintenance and repair
(3) Training
(4) Design, consulting, project planning
(5) Software development
(6) Remote support for clients
(7) Revamping or modernization
(8) End of life services

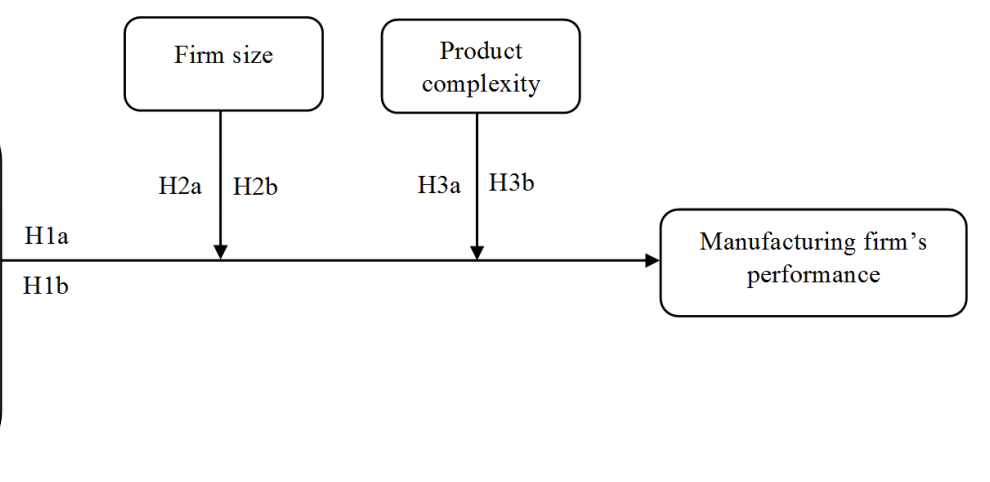

Figure 1. Proposed theoretical model 
ropean Manufacturing Survey, a survey on manufacturing strategies, application of innovative organizational and technological concepts in production, and questions of servitization in the European manufacturing industry [49], [50]. At the firm level, the EMS includes detailed information on innovation input, including R\&D expenditure, innovation output such as the introduction of new products to the market, qualification structure of the employees, and a number of control variables, such as firm size, exports, the position of the firm in the value chain, or characteristics of the main product and of the production process [51]. In addition, data are collected on performance indicators such as productivity, flexibility, quality and returns [52]. The EMS is administered by the Fraunhofer Institute for Systems and Innovation Research [53]. The objective of this regular, triennial questionnaire is to systematically monitor the innovation behaviour of European manufacturing enterprises at the firm level. The concepts, constructs and questions are well-tested and have been agreed upon in the EMS consortium. The eight-page questionnaire includes questions on innovation activity, firm and industry characteristics, and general firm data. The survey is sent out repeatedly to senior managers of firms with 20 or more employees and designed to be representative of all regions, industrial sectors covered, and enterprise sizes. The survey is conducted among manufacturing firms, addressing manufacturing sites (NACE Rev. 2 codes from 10 to 33). A non-response analysis is conducted to ensure that the sample is representative of the population. The analytical dataset includes 474 observations of manufacturing firms from three European countries (i.e. Croatia, Serbia and Slovenia). The dataset in our research is from the 2015 survey edition. The comparison of data regarding firm size distribution between Croatian, Serbian, and Slovenian subsamples, and those of other EMS countries (e.g. Germany, Spain, Austria, the Netherlands) shows no significant size bias. For all subsamples, no significant differences compared to the data of other EMS countries were observed.

With regard to descriptive statistics, the sampled firms report, on average, a firm size of 101 employees $(\mathrm{SD}=239)$. In total, 157 companies are small firms (fewer than 50 employees), 240 companies are medium-sized (between 50 and 249 employees), and 77 firms are large enterprises (more than 250 employees). Firms belonging to the fabricated metal products (91 firms), food products (61 firms) and machinery and equipment (44 firms) sectors account

Table 1. EMS database - distribution of firms by country and size

\begin{tabular}{|c|c|c|c|c|}
\hline & & & Firm size & \\
\hline & $\begin{array}{l}\text { Country } \\
\text { sample } \\
\text { n (\%) }\end{array}$ & $\begin{array}{c}20 \text { to } 49 \\
\text { employees } \\
n(\%)\end{array}$ & $\begin{array}{c}50 \text { to } 249 \\
\text { employees } \\
\text { n (\%) }\end{array}$ & $\begin{array}{c}250 \text { and more em- } \\
\text { ployees } \\
\text { n (\%) }\end{array}$ \\
\hline Croatia & $104(21.9)$ & $31(29.8)$ & $47(45.2)$ & $26(25.0)$ \\
\hline Serbia & $280(59.1)$ & $107(38.2)$ & $141(50.4)$ & $32(11.4)$ \\
\hline Slovenia & $90(19.0)$ & 19 (21.1) & $52(57.8)$ & 19 (21.1) \\
\hline Total & $474(100.0)$ & & & \\
\hline
\end{tabular}

Table 2. Classification of manufacturing sectors according to share in the total sample

\begin{tabular}{lcc}
\hline NACE & Manufacturing industry & Share in total sample (\%) \\
\hline 25 & Manufacture of fabricated metal products & 19.2 \\
10 & Manufacture of food products & 12.9 \\
28 & Manufacture of machinery and equipment n.e.c. & 9.4 \\
22 & Manufacture of rubber and plastic products & 8.4 \\
27 & Manufacture of electrical equipment & 5.7 \\
23 & Manufacture of other non-metallic mineral products & 5.3 \\
13 & Manufacture of textiles & 4.3 \\
29 & Manufacture of motor vehicles, trailers and semi-trailers & 4.3 \\
14 & Manufacture of wearing apparel & 4.3 \\
18 & Printing and reproduction of recorded media & 3.9 \\
31 & Manufacture of furniture & 3.5 \\
\end{tabular}


for the most prominent observations in the sample. Tables 1 and 2 depict the sample distribution across the participating European countries.

To analyse the relationship between product-related services and a firm's revenue, we employed linear and robust OLS regressions.

\section{Results}

Table 3 presents two different linear regression models, for a dependent variable (share of turnover), used to test H1a and H1b.

In the regression model that tests H1a: the impact of the deployment of a specific service portfolio choice on the share of revenue (directly charged), the overall model was significant, adjusted R2 $=.183, \mathrm{~F}$ $=8.125, \mathrm{p}<.001$. Two predictors had a significant coefficient - Software development $(\mathrm{B}=.299, \mathrm{p}<$ $.01)$ and Revamping or modernization $(\mathrm{B}=.226, \mathrm{p}<$ $.01)$. The second regression model that tests H1b (indirectly charged) was also significant, with the adjusted $\mathrm{R} 2=.368, \mathrm{~F}=20.363$, and $\mathrm{p}<.001$. Installation
$(\mathrm{B}=.923, \mathrm{p}<.001)$ and Design, consulting, project planning $(\mathrm{B}=.199, \mathrm{p}<.001)$ had coefficients that are positively and highly significant, thus supporting the idea to include them in the product price when billing to increase the share of revenue. However, manufacturing firms focusing on the development of services such as Maintenance and repair $(\mathrm{B}=-.587, \mathrm{p}$ $<.001)$ and Training $(\mathrm{B}=-.973, \mathrm{p}<.001)$ show negative effects on the share of revenue when indirectly charged.

H2a assumes that servitization increases with firm size. Figure 2 plots the service share on turnover for different employee size classes. Service turnover of small manufacturing enterprises (up to 50 employees) is $9.7 \%$. The share decreases in medium-sized firms between 50 and 249 employees to $7.6 \%$ and $6.1 \%$, respectively, reaches the minimum in firms with 250-499 employees, and then rises again. The service share is highest in very large firms with 1000 and more employees. Hence, our results provide support to partly reject $\mathrm{H} 2 \mathrm{a}$.

H3a states that servitization increases with product complexity. We assume that this impact is related

Table 3. Results of linear regressions

\begin{tabular}{|c|c|c|}
\hline Product-related services & Model 1: H1a & Model 2: H1b \\
\hline Installation & -.050 & $.923 * * *$ \\
\hline Maintenance and repair & .141 & $-.587^{\star \star \star}$ \\
\hline Training & .228 & $-.973^{* * *}$ \\
\hline Design, consulting, project planning & .013 & $.199 * * *$ \\
\hline Software development & $.299 * *$ & -.027 \\
\hline Remote support for clients & -.281 & -.220 \\
\hline Revamping or modernization & $.226^{* *}$ & .057 \\
\hline End of life services & .112 & .024 \\
\hline $\mathrm{R}$ & 0.428 & 0.606 \\
\hline $\mathrm{R}^{2}$ & 0.183 & 0.368 \\
\hline $\mathrm{F}$ & 8.125 & 20.363 \\
\hline Sig. & 0.000 & 0.000 \\
\hline
\end{tabular}

Note: ${ }^{* * *} \mathrm{p}<0.001 ;{ }^{* *} \mathrm{p}<0.01 ;{ }^{*} \mathrm{p}<0.05$

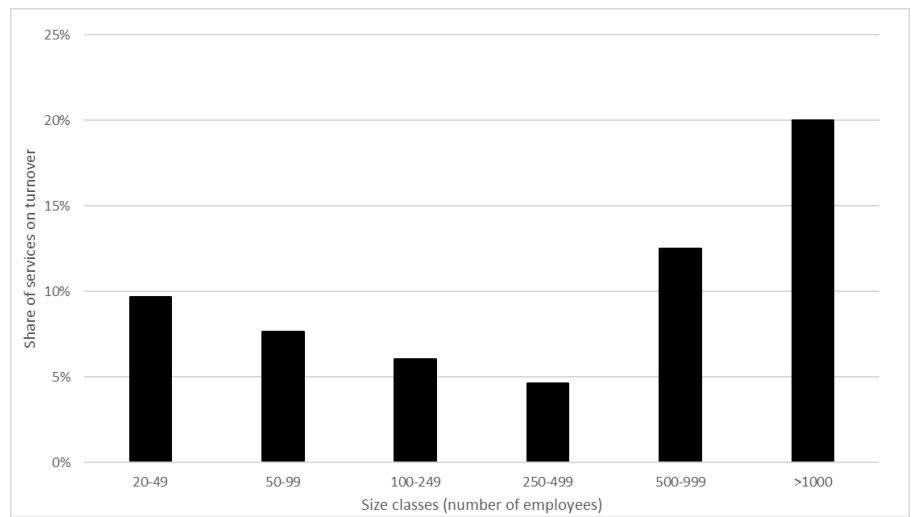

Figure 2. Services as a share of total turnover in manufacturing by firm size. Source: EMS 
to the differences in the production process measured by the degree of product complexity and servitization. Figure 3 depicts servitization indicator and different levels of product complexity. Rising degrees of product complexity are significantly related to a higher degree of servitization, supporting H3a.

Table 4 reports the moderating effects of the robust OLS regressions (H2b and $\mathrm{H} 3 \mathrm{~b}$ ). As the dependent variable we used the sum of the shares of revenue as a proxy for the firm's performance, both directly and indirectly charged. The regression coefficients for the independent variables reflect the influence on the dependent variable at the average value of the moderator variables, and the interpretations of the moderators remain unaffected [54]. Model 1 incorporates all product-related services. As a robustness check, Model 2 and Model 3 successively add one of the moderators - size and product complexity.

The findings regarding the moderating effects of firm size on the product-related services support our hypothesis. That is, in support of $\mathrm{H} 2 \mathrm{~b}$, firm size moderates the impact of breadth of the product-related service portfolio on the firm's share of revenue (B
$=7.06, \mathrm{p}<.01)$. Finally, we hypothesized that product complexity strengthens firm performance of the service portfolio $(\mathrm{B}=0.73, \mathrm{p}<.05)$. Thus, our results provide support for $\mathrm{H} 3 \mathrm{~b}$.

\section{Discussion}

As a major finding, our research indicates that the deployment of specific service portfolio choices will exhibit distinct financial performance, when differently charged, directly or indirectly. In other words, a billing option should be considered for product-related services. For instance, our results indicate that manufacturing firms should directly invoice software development and revamping or modernization as product-related services to maximize a firm's turnover and create a service business model. It is not clear from our data, however, whether the success of the two product-related services is due to the additional managerial focus these organizations received, or if, as we assume, cultural practices of customers in emerging markets are responsible for thwarting the

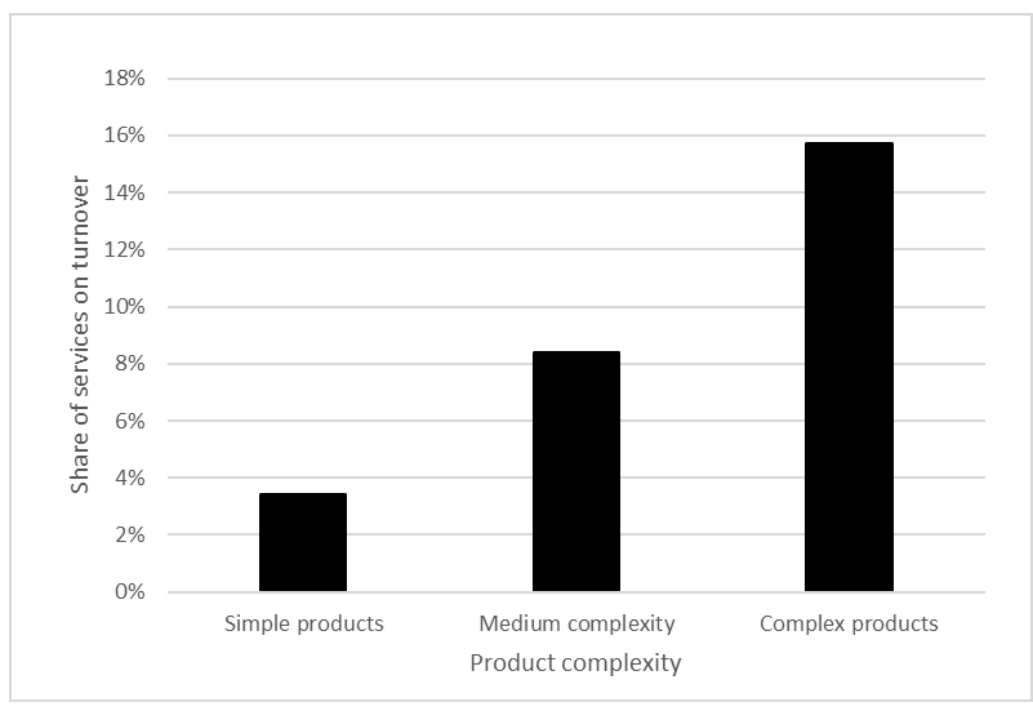

Figure 3. Servitization by product complexity. Source: EMS

Table 4. Results of OLS regressions

\begin{tabular}{|c|c|c|c|c|c|c|c|}
\hline & & \multirow{2}{*}{\multicolumn{2}{|c|}{$\begin{array}{c}\text { Model } 1 \\
\text { R2 = } 0.06\end{array}$}} & \multirow{2}{*}{\multicolumn{2}{|c|}{$\begin{array}{l}\text { Model } 2 \\
\text { R2 = } 0.28\end{array}$}} & \multirow{2}{*}{\multicolumn{2}{|c|}{$\begin{array}{l}\text { Model } 3 \\
\text { R2 = } 0.33\end{array}$}} \\
\hline & & & & & & & \\
\hline & & Coef. & p & Coef. & $\mathrm{p}$ & Coef. & p \\
\hline & PRS & 0.25 & & $.00 * *$ & 0.82 & 0.64 & $.00^{* *}$ \\
\hline & SIZE & & & & -1.29 & -0.87 & $.00^{* *}$ \\
\hline \multirow[t]{2}{*}{$\mathrm{H} 2 \mathrm{~b}$} & SIZE $\times$ PRS & & & & 10.60 & 7.06 & $.00^{* *}$ \\
\hline & COMPLEX & & & & & -0.57 & .10 \\
\hline $\mathrm{H} 3 \mathrm{~b}$ & COMPLEX $\times$ PRS & & & & & 0.73 & $.04^{*}$ \\
\hline
\end{tabular}

Note: $\mathrm{PRS}=$ product-related services; SIZE = firm size; COMPLEX = product complexity; ${ }^{* \star} \mathrm{p}<.01$ (one-tailed test); $\mathrm{*} \mathrm{p}<.05$ (one-tailed test). 
other services investigated in this research (i.e. installation, maintenance, training, design and remote support).

While it is possible for a firm to provide product-related services within the context of a manufacturing operation, we found that firms that were billing services such as maintenance and repair, and training indirectly had not achieved a bigger share of turnover. These results are in line with previous studies [29]. It practically implies that manufacturing firms should not indirectly invoice services such as maintenance and repair and training since they will significantly decrease the firm's share of revenue. This does not mean that firms should not increase their turnover when offering such services but will struggle to achieve service growth in overall revenue. Our results indicate that manufacturing firms offering maintenance and repair and training are still more product rather than service-oriented firms. Based on the results, some of the product-related services did not have statistically significant coefficients (i.e. remote support for clients, end of life services). These results imply that the personnel responsible for management of product-related services in manufacturing firms should reconsider their strategy since the current business model is not providing a valuable way of achieving great success.

Our results clarify the relationship between firm characteristics (i.e. firm size, product complexity) and servitization. Contrary to the literature reviewed [6], [10], [31], [38], [39], we also find high degrees of servitization in small firms. However, our results are in line with the previous literature in regards to product complexity and degree of services [4], [27].

\subsection{Theoretical implications}

This study contributes to the understanding of servitization in manufacturing. Production management research holds that not enough is known about service portfolio antecedents and their impact on firm performance since the majority of previous studies concentrated on services as a bundle [6]-[10], [18]. Thus, we take an initial step toward formulating a model that simultaneously analyses the financial impact of specific product-related services in manufacturing. More specifically, this study unravels the billing option strategy for services by comparing direct and indirect charging of services. As such, we extend the work of Paiola et al. [11] and Lay et al. [22] [22] to find that the billing option strategy for achieving service growth does matter, and that some services need to be charged directly and others indirectly. Our findings advise manufacturing firms to differently charge for product-related services to achieve service growth in overall revenue.

Our results show that firm size affects the financial performance of service activities in manufacturing markets. Regardless of the financial situation, firm size is an important precondition for a successful strategic change to services [4], [31]. While previous literature provides different results with regard to the moderating role of firm size [9], [31], [39], our findings highlight the importance of this organizational characteristic. In particular, small and large firms have advantages in the process of servitization which explains a U-shaped relationship between firm size and servitization. Small firms are more flexible and can exist in niche markets, for example by tailoring their services to the needs of one specific customer. Servitization of large manufacturing companies requires incremental investments in staff and capital and, thus, larger firms would benefit more from product-related services [4], [31], [39]. Faced with profit-reducing actions, medium size firms need to find new ways to secure their turnover streams.

Our study extends previous research on servitization by showing that the importance of service-performance relationship also depends on product complexity. This is particularly true since complex products and systems often require a range of services, whereas simple products require only delivery, or could be installed by users [55]. However, Raddats et al found that manufacturers of less complex products appeared more focused on stabilising revenue streams and increasing profitability through services than manufacturers of more complex products [27]. In contrast to this, our findings suggest the opposite. Thus, before increasing the complexity of products to achieve a greater turnover form services, manufacturers need to analyse if the set of appropriate resources and knowledge sources is in place to master the service transition. Our results are in line with the research from the previous EMS study. The relationship between servitization and product complexity points to the fact that a servitization strategy may yield the best results in manufacturing firms with complex products. This finding is in line with the servitization literature presented in the literature review above [4], [17], [27], [48].

\subsection{Practical implications}

Our findings provide novel insights into how service portfolio antecedents influence the share of revenue. Specifically, managers in manufacturing firms should directly invoice services such as software development and revamping or modernization, and 
indirectly bill fees for installation and design, consulting and project planning, to maximize the share of turnover from services. However, managers should be aware that not all service provisions will lead to a service business model. They should redesign the current service business model or withdraw remote support for clients and end of life services from their service portfolio. As suggested by Gebauer et al., utilization of services in manufacturing firms represents a challenge since some manufacturers find it extremely difficult to successfully exploit the potential of an extended service business [55].

For decision makers in industry, interested in moving toward service, this research also provides an in-depth understanding of the contextual factors affecting the financial performance of product-related services, such as firm size and product complexity. Specifically, large firms tend to achieve superior financial performance from the product-related services compared to small and medium ones. Managers in medium size manufacturing firms need to objectively assess their resources and to realize that service transition is a resource-intensive endeavour, and firms must allocate financial, managerial, and personnel resources to the service business to compete with small and large incumbents. Finally, our results indicate that manufacturing firms focused on complex products are more likely to reap the fruits of their product-related service activities. In other words, the results show that manufacturing firms which produce complex products and systems will increase their overall share of turnover from product-related services, further implying that firms focusing on either simple or products with medium complexity often fail to fully address what a customer is looking for. Manufacturers of simple products realize that services are not necessarily the best approach to increase profitability, since service-based offerings are not so dependent on being the original equipment manufacturer but are based on undertaking activities that could be run in-house by the customer, and therefore can be benchmarked for price and quality [4], [27].

\section{Conclusion}

This study examines servitization strategies of manufacturing firms. Consequently, this paper provides theoretical and practical implications on how and in what way product-related services impact the manufacturing firm revenue structure. The empirical results indicate that product-related services significantly influence a firm's share of revenue when invoiced directly and indirectly (included in the product price). Today, many manufacturing firms are evolving their business strategy from the traditional focus on product offerings toward a new direction, so that business models based on services can bring higher performance [1], [18]. Our results indicate actionable insights for managers of manufacturing firms to expand their understanding of how to increase the share of revenue generated from services and achieve service growth strategies.

Our sample was collected from all manufacturing industries, and, perhaps due to the industry specificity, results could differ. Also, there are various aspects that should be taken into consideration for the assessment of service impact on a firm's turnover (e.g. type of customer served, seasonality, and promotion). Further research is necessary to assess the experience and challenges of firms with a focus on one industry (i.e. the manufacture of fabricated metal products) and to consider different challenges in measuring the impact of services provided by manufacturing firms. Development of these ideas could prove especially useful for firms facing the challenges of a particular industry, showing that specific services can improve their financial performance [7], [56]. The intention is to conduct this type of empirical research again over a certain period, as the EMS is a survey which is carried out on a triennial basis. In this way, we will be able to measure to what extent the introduction of services affects the turnover of manufacturing firms over time. In addition, the next EMS survey should include "digital services" which are offered based on ICT functionalities of a product [57]. In this manner, research results could reveal a possible strategy for emerging economies to take a lead and get closer to developed countries.

\section{Funding}

This work was supported by the Croatian Science Foundation under Grant O-1861-2014 - 3535 Building competitiveness of Croatian Manufacturing.

\section{References}

[1] A. Ziaee Bigdeli, O. F. Bustinza, F. Vendrell-Herrero, and T. Baines, "Network positioning and risk perception in servitization: evidence from the UK road transport industry,” Int. J. Prod. Res., vol. 56, no. 6, pp. 2169-2183, 2018.

[2] T. Baines, A. Ziaee Bigdeli, O. F. Bustinza, V. G. Shi, J. Baldwin, and K. Ridgway, "Servitization: revisiting the state-of-the-art and research priorities," Int. J. Oper. Prod. Manag., vol. 37, no. 2, pp. 256-278, Jan. 2017.

[3] J. A. Buzacott and M. Mandelbaum, "Flexibility in 
manufacturing and services: Achievements, insights and challenges," Flex. Serv. Manuf. J., vol. 20, no. 1-2, pp. 13-58, 2008.

[4] B. Dachs, S. Biege, M. Borowiecki, G. Lay, A. Jäger, and D. Schartinger, "Servitisation of European manufacturing: empirical evidence from a large-scale database," Serv. Ind. J., vol. 34, no. 1, pp. 5-23, 2014.

[5] S. Moro, P. A. Cauchick-Migue, and G. H. de S. Mendes, "Product-service systems benefits and barriers: an overview of literature review papers," Int. J. Ind. Eng. Manag., vol. 11, no. 1, pp. 61-70, 2020.

[6] F. F. Suarez, M. A. Cusumano, and S. J. Kahl, "Services and the Business Models of Product Firms: An Empirical Analysis of the Software Industry," Manage. Sci., vol. 59, no. 2, pp. 420-435, 2013.

[7] I. Visnjic Kastalli and B. Van Looy, "Servitization: Disentangling the impact of service business model innovation on manufacturing firm performance," J. Oper. Manag., vol. 31, no. 4, pp. 169-180, 2013.

[8] I. Visnjic, F. Wiengarten, and A. Neely, "Only the Brave: Product Innovation, Service Business Model Innovation, and Their Impact on Performance,” J. Prod. Innov. Manag., vol. 33, no. 1, pp. 36-52, 2016.

[9] E. (Er) Fang, R. W. Palmatier, and J.-B. E. . Steenkamp, "Effect of Service Transition Strategies on Firm Value," J. Mark., vol. 72, no. 5, pp. 1-14, 2008.

[10] A. Eggert, J. Hogreve, W. Ulaga, and E. Muenkhoff, "Revenue and Profit Implications of Industrial Service Strategies,” J. Serv. Res., vol. 17, no. 1, pp. 23-39, 2014.

[11] M. Paiola, H. Gebauer, and B. Edvardsson, "Service Business Development in Small- to Medium-Sized Equipment Manufacturers," J. Business-to-bus. Mark., vol. 19, no. 1, pp. 33-66, 2012.

[12] L. Santamaría, M. Jesús Nieto, and I. Miles, "Service innovation in manufacturing firms: Evidence from Spain," Technovation, vol. 32, no. 2, pp. 144-155, 2012.

[13] M. J. Kim, C. Lim, and K. J. Kim, "A data-driven approach to designing new services for vehicle operations management,” Int. J. Ind. Eng. Theory Appl. Pract., vol. 25, no. 5, pp. 604-619, 2018.

[14] U. Weißfloch and J. Geldermann, "Assessment of product-service systems for increasing the energy efficiency of compressed air systems,” Eur. J. Ind. Eng., vol. 10, no. 3, pp. 341-366, 2016.

[15] Y. Shimomura, Y. Nemoto, T. Ishii, and T. Nakamura, "A method for identifying customer orientations and requirements for product-service systems design,” Int. J. Prod. Res., vol. 7543, no. December, pp. 1-11, 2017.

[16] W. Coreynen, P. Matthyssens, R. De Rijck, and I. Dewit, "Internal levers for servitization: How product-oriented manufacturers can upscale product-service systems," Int. J. Prod. Res., vol. 56, no. 6, pp. 2184-2198, 2018.

[17] F. Mahut, J. Daaboul, M. Bricogne, and B. Eynard, "Product-Service Systems for servitization of the automotive industry: a literature review," Int. J. Prod. Res., vol. 55, no. 7, pp. 2102-2120, 2017.

[18] I. Visnjic, D. Ringov, and S. Arts, "Which Service? How Industry Conditions Shape Firms' Service Type Choices," J. Prod. Innov. Manag., vol. 36, no. 3, pp. 381-407, Dec. 2019.

[19] K. Wang, Z. Jiang, N. Li, and N. Geng, "Optimal production control of a service-oriented manufacturing system with customer balking behavior," Flex. Serv. Manuf. J., vol. 26, no. 3, pp. 387-407, 2014.

[20] C. Kowalkowski, L. Witell, and A. Gustafsson, "Any way goes: Identifying value constellations for service infusion in SMEs," Ind. Mark. Manag., vol. 42, no. 1, pp. 18-30, 2013.

[21] S. Vandermerwe and J. Rada, "Servitization of business: Adding value by adding services," Eur. Manag. J., vol. 6, no.
4, pp. 314-324, 1988.

[22] G. Lay, G. Copani, A. Jäger, and S. Biege, "The relevance of service in European manufacturing industries," J. Serv. Manag., vol. 21, no. 5, pp. 715-726, 2010.

[23] S. Kinkel, E. Kirner, H. Armbruster, and A. Jager, "Relevance and innovation of production-related services in manufacturing industry,” Int. J. Technol. Manag., vol. 55, no. 3-4, pp. 263-273, 2011.

[24] H. Gebauer, "Service-driven manufacturing Provision, evolution and financial impact of services in industrial firm," J. Serv. Manag., vol. 23, no. 1, pp. 120-136, 2012.

[25] C. Kowalkowski, H. Gebauer, and R. Oliva, "Service growth in product firms: Past, present, and future," Ind. Mark. Manag., vol. 60, pp. 82-88, 2017.

[26] U. Marjanovic, B. Lalic, V. Majstorovic, N. Medic, J. Prester, and P. Iztok, "How to Increase Share of Product-Related Services in Revenue? Strategy Towards Servitization," in Advances in Production Management Systems. Smart Manufacturing for Industry 4.0, 2018, vol. 536, pp. 57-64.

[27] C. Raddats, T. Baines, J. Burton, V. M. Story, and J. Zolkiewski, "Motivations for servitization: the impact of product complexity," Int. J. Oper. Prod. Manag., vol. 36, no. 5, pp. 572-591, 2016.

[28] N. F. Ayala, W. Gerstlberger, and A. G. Frank, "Managing servitization in product companies: the moderating role of service suppliers,” Int. J. Oper. Prod. Manag., vol. 39, no. 1, pp. 43-74, 2018.

[29] R. Oliva and R. Kallenberg, "Managing the transition from products to services,” Int. J. Serv. Ind. Manag., vol. 14, no. 2, pp. 160-172, 2003.

[30] B. C. Skaggs and S. B. Droege, "The Performance Effects of Service Diversification by Manufacturing Firms.," J. Manag. Issues, vol. 16, no. 3, pp. 396-407, 2004.

[31] E. Böhm, A. Eggert, and C. Thiesbrummel, "Service transition: A viable option for manufacturing companies with deteriorating financial performance?," Ind. Mark. Manag., vol. 60, pp. 101-111, 2017.

[32] T. Lerher, M. Borovinsek, M. Ficko, and I. Palcic, "Parametric study of throughput performance in SBS/RS based on simulation," Int. J. Simul. Model., vol. 16, no. 1, pp. 96-107, 2017.

[33] S. Rakic, B. Lalić, M. Vilkas, N. Medic, and U. Marjanovic, "The impact of servitization on firm performance: moderating role of digital solutions," in 26th International EurOMA Conference, 2019, pp. 1-10.

[34] W. Wang, K. H. Lai, and Y. Shou, "The impact of servitization on firm performance: a meta-analysis," Int. J. Oper. Prod. Manag., vol. 38, no. 7, pp. 1562-1588, 2018.

[35] O. Benedettini, M. Swink, and A. Neely, "Examining the influence of service additions on manufacturing firms' bankruptcy likelihood," Ind. Mark. Manag., vol. 60, pp. 112-125, 2017.

[36] C. Kowalkowski, H. Gebauer, B. Kamp, and G. Parry, "Servitization and deservitization: Overview, concepts, and definitions," Ind. Mark. Manag., vol. 60, pp. 4-10, 2017.

[37] A. Eggert, J. Hogreve, W. Ulaga, and E. Muenkhoff, "Industrial services, product innovations, and firm profitability: A multiple-group latent growth curve analysis," Ind. Mark. Manag., vol. 40, no. 5, pp. 661-670, 2011.

[38] A. Eggert, C. Thiesbrummel, and C. Deutscher, "Heading for new shores: Do service and hybrid innovations outper form product innovations in industrial companies?," Ind. Mark. Manag., vol. 45, no. 1, pp. 173-183, 2015.

[39] A. Neely, "Exploring the financial consequences of the servitization of manufacturing," Oper. Manag. Res., vol. 1, no. 2, pp. 103-118, 2009.

[40] C. Kowalkowski, D. Kindström, T. B. Alejandro, S. Brege, and S. Biggemann, "Service infusion as agile incrementalism 
in action,”J. Bus. Res., vol. 65, no. 6, pp. 765-772, 2012.

[41] J. Gao, Y. Yao, V. C. Y. Zhu, L. Sun, and L. Lin, "Service-oriented manufacturing: a new product pattern and manufacturing paradigm,” J. Intell. Manuf., vol. 22, no. 3, pp. 435-446, 2011.

[42] A. Tukker, "Eight types of product-service system: eight ways to sustainability? Experiences from SusProNet," Bus. Strateg. Environ., vol. 13, no. 4, pp. 246-260, 2004.

[43] R. Wise and P. Baumgartner, "Go Downstream: The New Profit Imperative in Manufacturing," Harv. Bus. Rev., vol. 77, no. 5, pp. 133-141, Sep. 1999.

[44] H. Gebauer, M. Paiola, and B. Edvardsson, "Service business development in small and medium capital goods manufacturing companies,” Manag. Serv. Qual., vol. 20, no. 2, pp. 123-139, 2010.

[45] C. Grönroos and P. Helle, "Adopting a service logic in manufacturing: Conceptual foundation and metrics for mutual value creation,” J. Serv. Manag., vol. 21, no. 5, pp. 564-590, Oct. 2010.

[46] C. Windahl and N. Lakemond, "Integrated solutions from a service-centered perspective: Applicability and limitations in the capital goods industry,” Ind. Mark. Manag., vol. 39, no. 8, pp. 1278-1290, 2010.

[47] M. Hobday, "Product complexity, innovation and industrial organisation,” Res. Policy, vol. 26, pp. 689-710, 1998.

[48] M. Szwejczewski, K. Goffin, and Z. Anagnostopoulos, "Product service systems, after-sales service and new product development," Int. J. Prod. Res., vol. 53, no. 17, pp. 5334-5353, 2015.

[49] B. Lalic, V. Majstorovic, U. Marjanovic, M. Delić, and N. Tasic, "The Effect of Industry 4.0 Concepts and E-learning on Manufacturing Firm Performance: Evidence from Transitional Economy," in Advances in Production Management Systems. The Path to Intelligent, Collaborative and Sustainable Manufacturing, 2017, vol. 513, pp. 298-305.

[50] B. Lalic, S. Rakic, and U. Marjanovic, "Use of Industry 4.0 and organizational innovation concepts in Serbian textile and apparel industry," Fibres Text. East. Eur., vol. 133, no. 3, pp. 10-18, 2019.

[51] N. Medic, Z. Anisic, B. Lalic, U. Marjanovic, and M. Brezocnik, "Hybrid fuzzy multi-attribute decision making model for evaluation of advanced digital technologies in manufacturing: Industry 4.0 perspective," Adv. Prod. Eng. Manag., vol. 14, no. 4, pp. 483-493, 2019.

[52] B. Lalic, N. Medic, M. Delic, N. Tasic, and U. Marjanovic, "Open Innovation in Developing Regions: An Empirical Analysis across Manufacturing Companies,” Int. J. Ind. Eng. Manag., vol. 8, no. 3, pp. 111-120, 2017.

[53] Fraunhofer Institute for Systems and Innovation Research ISI, "European Manufacturing Survey," 2019. [Online]. Available: https:/www.isi.fraunhofer.de/en/themen/ industrielle-wettbewerbsfaehigkeit/fems.html\#tabpanel-1. [Accessed: 14-Jul-2019].

[54] J. F. Hair, W. C. Black, B. J. Babin, and R. E. Anderson, Multivariate Data Analysis, 7th ed. Prentice Hall, 2009.

[55] H. Gebauer, E. Fleisch, and T. Friedli, "Overcoming the service paradox in manufacturing companies," Eur. Manag. J., vol. 23, no. 1, pp. 14-26, 2005.

[56] Y. Ki and B. I. Kim, "Mass-customized outpatient appointment rule generator," Int. J. Ind. Eng. Theory Appl. Pract., vol. 26, no. 2, pp. 104-122, 2019.

[57] U. Marjanovic, S. Rakic, and B. Lalic, "Digital Servitization: The Next 'Big Thing' in Manufacturing Industries," in Advances in Production Management Systems. Production Management for the Factory of the Future, 2019, pp. 510-517. 